\title{
Article
}

\section{MMTV Prevalence in Breast Cancer Samples in Romania- Do Major Geographical Differences Exist in the World Population?}

\author{
Zsolt Fekete 1, Bristena Octavia Terțan 2, Lajos Ráduly ${ }^{3}$, Dan Tudor Eniu ${ }^{4}$, Rareș Buiga ${ }^{5}$, Mihaela Galatâr ${ }^{6}$ and Io- \\ ana Berindan-Neagoe ${ }^{7, *}$
}

1 Oncology-Radiotherapy, Dept. of Oncology, Iuliu Hațieganu University of Medicine and Pharmacy and Institute of Oncology "Prof dr. Ion Chiricuță“, Cluj-Napoca, Romania; fekete.zsolt@umfcluj.ro

2 Iuliu Hațieganu University of Medicine and Pharmacy and Institute of Oncology "Prof dr. Ion Chiricuță", Cluj-Napoca, Romania; bristena.t@gmail.com

3 Research Center for Functional Genomics, Biomedicine and Translational Medicine, Iuliu Hațieganu University of Medicine and Pharmacy; Lajos.raduly@umfcluj.ro

4 Oncological Surgery and Gynecologic Oncology, Dept. of Oncology, Iuliu Hațieganu University of Medicine and Pharmacy and Institute of Oncology "Prof dr. Ion Chiricuță", Cluj-Napoca, Romania; eniu.dan@iocn.ro

5 Pathology Dept., Institute of Oncology “Prof dr. Ion Chiricuță“, Cluj-Napoca, Romania; buiga.rares@iocn.ro

6 Pathology Dept., Institute of Oncology "Prof dr. Ion Chiricuță“, Cluj-Napoca, Romania; galatar.mihaela@iocn.ro

7 Research Center for Functional Genomics, Biomedicine and Translational Medicine, Iuliu Hațieganu University of Medicine and Pharmacy; ioana.neagoe@umfcluj.ro

* Correspondence: ZF, fekete.zsolt@umfcluj.ro; Tel.: 0040745544773 and BOT bristena.t@gmail.com

Simple Summary: Breast cancer, although the most frequently diagnosed malignant tumor in humans, has an unclear etiology compared to other frequent cancer types, such as lung cancer (more than $80 \%$ are due to smoking), cervical cancer (>90\% due to human-papilloma virus infection), colon cancer (mostly probably linked to dietary factors) and gastric cancer (linked to Helicobacter pylori), just to name a few. Mouse mammary tumor virus (MMTV) is the cause of most breast carcinomas in mice. MMTV's implication in human breast cancer is far less clear, despite of decades of research, with conflicting evidence on the presence of MMTV sequences in human breast cancer genome, ranging from 0 to $40 \%$. Our study aimed to quantify the existence of MMTV in breast cancer samples in Romania, the first of its kind in South-Eastern Europe. If MMTV plays a role in breast cancer's etiology, there is a possibility of prevention.

\begin{abstract}
Background: Mouse-mammary tumor virus (MMTV) might play a role in the etiology of some breast cancers in humans. The purpose of our study was to identify MMTV DNA sequences in breast tissue samples from breast cancer patients operated in our regional center from Romania. (2) Methods: We have selected 75 patients with non-metastatic breast cancer treated with curative intent and searched with PCR the MMTV-like DNA sequence in the breast cancer tissue and normal breast tissue obtained from the same patients. (3) Results: None of the examined samples was positive for MMTV-like target sequences on PCR. (4) Conclusions: We could not prove that MMTV plays a role in the etiology of breast cancer in our patient group. This finding is similar to findings of other geographically related research groups and might be due to the fact that only the Mus musculus domesticus mouse species was proven to carry infectious MMTV, but not the Mus musculus musculus species, which is specific to South-Eastern Europe and some parts of Asia.
\end{abstract}


Keywords: mouse mammary tumor virus 1; human breast cancer 2; risk factor 3

\section{Graphical abstract}

\begin{tabular}{|c|c|c|c|}
\hline Scientific background & Methods and cohort & Findings \\
\hline $\begin{array}{c}\text { MMTV is a betaretrovirus that causes } \\
\text { breast cancer in mice and dogs }\end{array}$ & $\begin{array}{c}\text { None of the probes examined } \\
\text { were positive for MMTV-like } \\
\text { target sequence }\end{array}$ \\
\hline
\end{tabular}

Citation: Lastname, F.; Lastname, F.; Lastname, F. Title. Cancers 2021, 13, x. https://doi.org/10.3390/xxxxx

Academic Editor: Firstname Lastname

Received: date Accepted: date Published: date

Publisher's Note: MDPI stays neutral with regard to jurisdictional claims in published maps and institutional affiliations.

\section{(c) (1)}

Copyright: (c) 2021 by the authors. Submitted for possible open access publication under the terms and conditions of the Creative Commons Attribution (CC BY) license (https://creativecommons.org/license s/by/4.0/). 


\section{Introduction}

In 2020, female breast cancer has surpassed lung cancer as the most commonly diagnosed cancer, with an estimated 2.3 million new cases (11.7\%), being also the leading cause of mortality due to cancer in female patients around the world. Among women, breast cancer accounts for 1 in 4 cancer cases and for 1 in 6 cancer deaths. Incidence rates are $88 \%$ higher in transitioned countries than in transitioning countries with the highest incidence rates $(>80$ per 100,000) in Australia/New Zealand, Western Europe (Belgium has the world's highest incidence), Northern America, and Northern Europe and the lowest rates $(<40$ per 100,000) in Central America, Eastern and Middle Africa, and South-Central Asia. [1]

Although there are various risk factors known for breast cancer, only about $10 \%$ of the cases have a precise genetic cofactor. Breast cancer associated gene 1 and 2 (BRCA1 and BRCA2) are two anti-oncogenes located on chromosome 17q21 and 13q12, respectively, and both encode tumor suppressor proteins. Totally, about $20-25 \%$ of hereditary breast cancers and $5-10 \%$ of all breast cancers are caused by BRCA1/2 mutations. [2] Family history of breast cancer is another major risk factor. [3] Women with a family history of breast cancer (two or more cases in women younger than 50 years or three or more cases at any age) who do not present BRCA mutations are approximately 11 times more likely to develop breast cancer. [4] Exogenous hormone use, such as contraceptives [5], ovulation-stimulating drugs [6] and some schedules of menopausal hormone replacement therapy [7] might also increase the risk of breast cancer. Other risk factors include obesity, alcohol consumption [8], radiation exposure or nulliparity. [2]

One retrovirus that has been used for many years for the study of cancer pathogenesis in mice is the Mouse Mammary Tumor Virus (MMTV). It was discovered in 1936 as a milk-transmitted agent. The agent was then demonstrated to have reverse transcriptase activity, similar to other retroviruses, and hormone-responsive elements in the viral genome that enhance viral replication during pregnancy. [9] In 1989 Harold Varmus was awarded the Nobel Prize for the observation that the insertion of MMTV proviral genome in host DNA resulted in the activation on proto-oncogenes. The majority of breast cancers in mice are caused by MMTV. [10]

Several studies examined the association between MMTV and human breast cancer. A major breakthrough came in 1972 with the identification of RNA in human breast cancer that was homologous to MMTV RNA. [11] Prior to the widespread use of PCR, MMTVrelated sequences in human breast cancer cells were identified by hybridization techniques. Using hybridization methods Szakacs \& Moscinski identified in DNA sequences homologous to the entire MMTV provirus using LTR- long terminal repeat, gag, pol and env probes in 7 (13\%) of 52 human breast cancers. [12] However, it was difficult to distinguish MMTV gene sequences from those of the human endogenous retrovirus (HERV). HERV gene sequences are very similar to MMTV and may be the remnants of MMTV viruses that have become integrated into the human genome over millennia [13]. This problem was overcome by the Beatriz Pogo group by their identification of MMTV envelope gene sequences which were unique to MMTV. [14].

Using PCR techniques directed at a $660 \mathrm{bp}$ highly conserved portion of the MMTVenv gene with only $16 \%$ homology to the prototype HERV-K10 human endogenous retrovirus, Wang et al. were able to demonstrate MMTV- env specific sequences in $38.5 \%$ of the 314 breast carcinomas and in $6.9 \%$ of the 29 breast fibroadenoma samples, compared to only $1.8 \%$ of 107 samples of normal breast reduction mammoplasty tissues. [15] A series of similar studies using PCR primers and nested primers were then conduced in an attempt to correlate the presence of the MMTV specific $660 \mathrm{bp}$ env sequence with mammary tumorigenesis. A meta-analysis published in 2019 analyzed 20 studies reported in 17 publications in which PCR was used to detect MMTV specific region identified by Wang et al; 11 studies showed a positive correlation between the presence of the indicative MMTV signal and breast tumor tissue at the $\mathrm{p}<0.01$ significance level. To further investigate the presence of a subfragment of the highly conserved MMTV env region, laser 
microdissection techniques were used to study breast cancer epithelial cells followed by real-time PCR analysis. [16] MMTV was identified in 40 (82\%) of 49 ductal carcinoma in situ specimens and 7 (35\%) of 20 invasive ductal carcinoma specimens compared to no identification in 20 normal breast specimens from reduction mammoplasty.

The aim of our study was to identify MMTV env viral sequences in surgical breast cancer tissue samples in Romania, to verify if in this part of South-Eastern Europe is there a possibility that some breast cancers might be related to MMTV infection.

\section{Materials and Methods}

We conducted a retrospective study in which we analyzed the presence of the MMTV env gene sequence in human breast cancer samples. The samples were collected from the tissue archive of the Oncological Institute of Cluj-Napoca. They were formalin-fixed paraffin-embedded breast tissue samples obtained from either mastectomies or lumpectomies of patients diagnosed with invasive ductal carcinoma between $2003-2011$. The patients selected for the study did not undergo neoadjuvant chemo- or radiotherapy.

For each patient, a pathologist (R.B.) examined the tissue samples obtained surgically and selected one tissue sample that contained tumoral tissue characteristic for invasive ductal carcinoma and one sample that contained normal peri-tumoral tissue. The formalin-fixed paraffin-embedded tissue samples were each sectioned at 10 micrometers and 56 sections were put into a tube, two tubes for each tumoral tissue and two tubes for each normal tissue, therefore 4 tubes corresponding to each patient.

DNA was extracted from deparaffinized sections of each paraffin block using PureLink ${ }^{\circledR}$ Genomic DNA Kit (Invitrogen), K182001, as instructed by the manufacturer.

The PCR reaction for the selected samples was performed with Thermo Scientific Phusion High-Fidelity PCR Master Mix according to the recommended protocol from a $200 \mathrm{ng}$ total concentration of DNA. The condition used for polymerase chain reaction was $98{ }^{\circ} \mathrm{C} / 30$ s for initial denaturation, $98{ }^{\circ} \mathrm{C} / 10 \mathrm{~s}, 61^{\circ} \mathrm{C} / 30 \mathrm{~s}$ and $72{ }^{\circ} \mathrm{C} / 30$ s for denaturation annealing and extension and $72{ }^{\circ} \mathrm{C} / 10 \mathrm{~min} .4^{\circ} \mathrm{C} /$ hold for final extension in a Veriti ${ }^{\mathrm{TM}} 96$ Well Thermal Cycler (ThermoFisher Scientific). Positive and negative controls were included in each run.

For the electrophoresis a 3\% agarose gel was used with a ThermoFisher Scientific GeneRuler Low Range DNA ladder. A 104 base pair oligonucleotide was ordered based on the gene bank MMTV-like virus envelope protein (ACCESSION \#: GU109516) and was used as a positive control. The primer used was MMTV env gPr73 [Mouse mammary tumor virus] forward, 5'-GATGGTATGAAGCAGGATGG-3' and reverse, 5'ССTCTTTTCTCTATATCTATTAGCTGAGGTAATC-3'.

\section{Results}

\subsection{Patients and results of PCR}

\subsubsection{Patients}

We selected 75 patients with ages between 32 and 77 years old; 25 patients underwent modified radical mastectomy and 50 patients were treated with lumpectomy The characteristics of the patients and the descriptors of the tumors are summarized in Table 1.

\subsubsection{PCR results}

The samples with an insufficient quantity of tissue or a very low concentration of DNA were excluded from the study, as shown in supplementary Tables 1 and 2. More precisely, for some cases, when realizing $10 \mu \mathrm{m}$ sections for obtaining either tumor or normal tissue we could not obtain at minimum 5 sections for each tube, so these samples had to be excluded. From the lumpectomy group, out of 50 tumoral tissue samples, 48 
remained for further analysis and out of these 48 samples 40 had sufficient quantity of DNA. Out of 50 normal tissue samples, in 32 cases there was sufficient tissue, but only 18 were kept in the study as samples with proper DNA content. From the mastectomy group, out of 25 tumor tissue samples, 23 had an optimal concentration of DNA, and out of 20 normal tissue samples with sufficient material only 13 were kept in the study for further investigations, for the same reasons. (Fig. 1) Therefore, after DNA extraction, in the lumpectomy group, there were 40 tumor samples and 18 normal tissue samples, while in the mastectomy group there were 23 tumor samples and 13 normal tissue samples.

As a final result, none of the examined samples was positive for MMTV-like target sequences on PCR. 


\subsection{Figures and Tables}

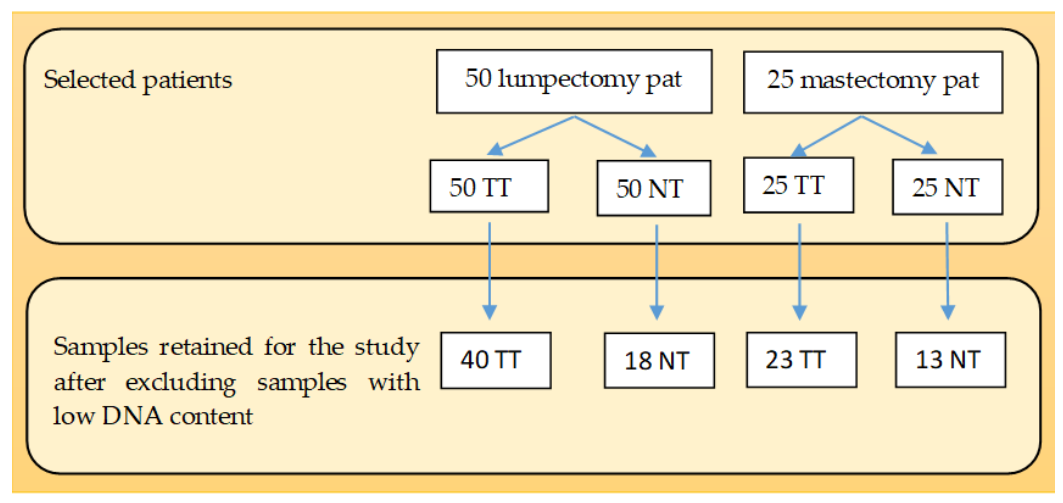

Figure 1. Samples retained for PCR after excluding samples with low tissue and DNA content.

Table 1. Patient's characteristics

\begin{tabular}{|c|c|c|c|}
\hline \multicolumn{2}{|c|}{ Variable } & \multirow{2}{*}{$\begin{array}{c}\text { Number } \\
54.29\end{array}$} & \multirow[t]{2}{*}{$\%$} \\
\hline Mean age (years) & & & \\
\hline \multirow[t]{6}{*}{ Stage } & IA & 17 & 22.67 \\
\hline & IIA & 31 & 41.33 \\
\hline & IIB & 11 & 14.67 \\
\hline & IIIA & 5 & 6.67 \\
\hline & IIIB & 3 & 4 \\
\hline & IIIC & 8 & 10.66 \\
\hline \multirow{3}{*}{$\begin{array}{l}\text { Histologic grade } \\
\text { (Nottingham score) }\end{array}$} & I & 13 & 17.33 \\
\hline & II & 23 & 30.66 \\
\hline & III & 39 & 52 \\
\hline \multirow{2}{*}{ Estrogen receptors } & Positive & 58 & 77.33 \\
\hline & Negative & 17 & 22.66 \\
\hline \multirow{2}{*}{ Progesterone receptors } & Positive & 53 & 70.66 \\
\hline & Negative & 22 & 29.33 \\
\hline \multirow{2}{*}{ HER-2 receptors } & Positive & 29 & 38.66 \\
\hline & Negative & 46 & 61.33 \\
\hline Triple negative & & 16 & 21.33 \\
\hline
\end{tabular}

\section{Discussion}

Breast cancer is both an ancient disease, first described by the Egyptians [17], and a disease of civilization, since its incidence has increased in the last century.

In mice, MMTV can be transmitted horizontally as an infectious particle containing viral RNA or vertically in the murine germline as an endogenous proviral DNA genome. MMTV replicates in the mothers' mammary glands where the infectious B-type particles accumulate in milk. When the nurslings ingest the virus, it invades the gut-associated lymphoid tissues and infects B- lymphocytes. To aid viral replication, MMTV uses a superantigen, encoded by the orf gene in the viral long terminal repeat (LTR) region, to activate specific T-lymphocyte subsets. This serves to stimulate viral replication as well as clonal amplification of $\mathrm{T}$ lymphocytes, which provides a vehicle for viral passage from the gut-associated tissue to the breast. Although viral replication is maximal in the breast epithelium, hormone stimulation is still required to activate the corticosteroid response elements in the retroviral LTR. During pregnancy, viral replication is increased, which leads to hyperplastic nodule formation that can eventually lead to tumor formation. [18] MMTV 
can also be transmitted to offspring as proviral DNA in a Mendelian fashion. MMTV does not contain an oncogene, but it has been shown that proviral DNA can integrate close to cellular proto-oncogenes and enhance their activity. [19]

But what is MMTV's role in human breast cancer on the globe? Our results are similar with the results of a series of studies that could not detect the presence of the MMTV in human breast cancer samples. Tabriz et al. [20] evaluated the same MMTV-like target sequence as us by RT-PCR using the same primers, and did not detect any virus particle in breast cancer tissues of 40 Iranian women. Perzova et al. [21] analyzed the prevalence of MMTV env sequences in 66 samples of FFPE or snap-frozen biopsies of breast tissue (US patients) by PCR and took supplementary measures to prevent carry-over contamination with murine DNA; they concluded that the MMTV copy numbers detected in the breast cancer specimens were too low to be derived from a monoclonally integrated expanded tumor cell sample. Fukuoka et al. [22] investigated in Japan 46 breast cancer patients and 3 patients with benign mammary tumors and used PCR and Southern blot hybridization; they could not detect the MMTV env gene-like sequence in any of the samples tested.

However, there are several reports on the MMTV env gene in human breast cancer samples. [15], [23], [24], [25] Additionally Johal et al. found MMTV like virus sequences by PCR in 5\% (4/91) of breast milk samples from healthy lactating women from Australia, [26]. Furthermore, MMTV-like sequences were found in the saliva [27] and peripheral blood lymphoid cells [28], suggesting that viral transmission in humans is similar to that seen in mice, occurring via breastfeeding and infection of mucosa-associated lymphocytes before reaching the breast tissue.

The contrast between the different outcomes of the studies may indicate that there is a regional virus epidemiology. Our study is the first one in Romania and even SouthEastern Europe which analyzes the prevalence of MMTV virus infection in human breast tissue. Based on our sample the results indicate that breast cancer is not likely to be related to the MMTV infection in Romania. The negative result is most likely explained by the transmission vectors of the virus and the geographic distribution of Mus musculus sp. domesticus - the native MMTV reservoir. It has been proposed that a higher prevalence in some areas of Mus musculus domesticus in the vicinity of humans, which is the species of mouse that carries the infectious MMTV, is correlated to a higher prevalence of human breast cancer. [29] M. m. domesticus seems to be less present in South-Eastern Europe, where M. m. musculus is the predominant species [30]. In relationship to MMTV this variability of species needs to be further explored, but we found no reports of naturally occurring MMTV infection in M. m. musculus. Callahan et al [31] studying several feral mouse species stated that M. m. musculus specimens from Czechoslovakia did not carry MMTV, although all mice species studied had small fragments of inserted MMTV which is explained by the "accumulation of evolutionarily divergent MMTV-alpha insertions into the mouse germ line". Ford et al [24] could not identify MMTV in first-generation Australian-Vietnamese women, in comparison to Caucasian-Australian woman (42.2\%). It is known that in South-Eastern Asia the dominant mouse species is not M. m. domesticus, but M. m. castaneus.

Furthermore, even Mus musculus sp. domesticus, also known as "western house mouse", since it's spread to Europe from Asia in the postglacial period [32], clustered in somewhat different local populations [33], and local subpopulations may have different rates of infection with MMTV, which might explain the variable positivity of MMTV in Western countries, ranging 20-40\%. Another reason for the variability of the rate of association of MMTV to human breast cancer is the presence of a possible intermediary host, the dog. Laumbacher et al [34] studied dog-human contact epidemiologically in Bavaria, Germany and found that more than twice the number of breast cancer patients kept dogs permanently in the last 10 years leading up to the diagnosis compared to control individuals (37.7\% vs. $14.8 \%$, $\mathrm{p}=0.0000003$, relative risk 3.5$)$.

Because breast cancer is more prevalent among women of higher socio-economic status, it has been hypothesized that this may be due to a late exposure to MMTV infection 
from mice, as compared to infection during early life among girls of low socio-economic status and hence early immunity. [35]

As human breast cancer progresses, the MMTV viral load increases but it falls in latestage invasive breast cancer. [16] The lack of identification of MMTV in advanced breast cancer may be due to the breakdown of cell physiology, but our patient sample consisted of early stage, non-metastatic breast cancer patients.

Another explanation for the divergent results regarding the MMTV infection in humans might be that some positive results were due to carry-over contamination of human samples with previously amplified murine MMTV DNA. Rodent DNA might be present in the building's walls and ventilation systems, most likely as small particulate matter. [21] We consider this scenario very unlikely in all of the MMTV-positive studies, although might have had happened in some, taking into account the extreme measures taken to avoid contamination by most of the laboratories.

While it is clear that the association between MMTV infection and human breast cancer is still a debatable topic, most results indicate that a correlation cannot be ruled out. Proving that MMTV is an etiologic agent for human breast cancer will probably require non-PCR based traditional retrovirology techniques such as virus isolation and determination of monoclonal integration in tumor cells. This would certainly be a breakthrough in oncology and would open the gates to the prevention of breast cancer through (1) hygiene measures, (2) counseling of those less than 5\% of MMTV-infected women to find alternatives to breastfeeding and (3) the development of a vaccine. If in Western countries and Australia the involvement of MMTV in breast cancer probably occurs in $20-40 \%$ of patients, such measures would lead to a proportional reduction of newly diagnosed breast cancer cases in about one or two generations. MMTV-related breast cancers tend to be less aggressive as well. [36]

Other virus infections have been proposed as well as causative agents of breast cancer, the most studied being bovine leukemia virus (BLV). [37]

Breast cancer remains one of the most mysterious human cancers, since most cases cannot be linked to specific risk factors.

\section{Conclusions}

We have shown that MMTV is not present in our region in breast tissue samples obtained from breast cancer patients. The same result was achieved by other geographically related research groups. Only Mus musculus domesticus mouse species was proven to carry infectious MMTV, thus our results can be explained by the variable local distribution of different mice species.

Supplementary Materials: The following are available online at www.mdpi.com/xxx/s1, Table S1: Mastectomy samples, DNA extraction results. Abbreviations: TT=tumoral tissue, TN=normal tissue, Table S2: Lumpectomy samples, DNA extraction results. Abbreviations: TT=tumoral tissue, $\mathrm{TN}=$ normal tissue.

\begin{tabular}{llllllll} 
\# & $\begin{array}{l}\text { Sample } \\
\text { ID }\end{array}$ & $\begin{array}{l}\text { DNA } \\
\text { Conc. }\end{array}$ & Unit & $\mathbf{2 6 0 / 2 8 0}$ & $\mathbf{2 6 0 / 2 3 0}$ & $\begin{array}{l}\text { (200ng) } \\
\text { H2O }\end{array}$ \\
\hline 1 & $1 \mathrm{M} \mathrm{TN}$ & 2 & $\mathrm{ng} / \mu \mathrm{l}$ & 1.36 & 0.87 & 100.00 & -76.00 \\
\hline 2 & $2 \mathrm{M} \mathrm{TN}$ & 5.8 & $\mathrm{ng} / \mu \mathrm{l}$ & 1.55 & 1.38 & 34.48 & -10.48 \\
\hline 3 & $3 \mathrm{M} \mathrm{TN}$ & 39 & $\mathrm{ng} / \mu \mathrm{l}$ & 1.68 & 2.26 & 5.13 & 18.87 \\
\hline 4 & $4 \mathrm{M} \mathrm{TN}$ & 0.2 & $\mathrm{ng} / \mu \mathrm{l}$ & -2.53 & -0.05 & 1000.00 & -976.00 \\
\hline 5 & $6 \mathrm{M} \mathrm{TN}$ & 9.7 & $\mathrm{ng} / \mu \mathrm{l}$ & 1.53 & 1.19 & 20.62 & 3.38 \\
\hline 6 & $7 \mathrm{M} \mathrm{TN}$ & -1.5 & $\mathrm{ng} / \mu \mathrm{l}$ & 3.79 & 0.18 & -133.33 & 157.33 \\
\hline 7 & $8 \mathrm{M} \mathrm{TN}$ & 6.4 & $\mathrm{ng} / \mu \mathrm{l}$ & 1.69 & 1.66 & 31.25 & -7.25 \\
\hline 8 & $9 \mathrm{M} \mathrm{TN}$ & 44.9 & $\mathrm{ng} / \mu \mathrm{l}$ & 1.71 & 2.57 & 4.45 & 19.55
\end{tabular}




\begin{tabular}{|c|c|c|c|c|c|c|c|}
\hline 9 & $10 \mathrm{M} \mathrm{TN}$ & 15.9 & $\mathrm{ng} / \mu \mathrm{l}$ & 1.72 & 2.59 & 12.58 & 11.42 \\
\hline 10 & $11 \mathrm{M}$ TN & 1.1 & $\mathrm{ng} / \mu \mathrm{l}$ & 1.81 & -0.39 & 181.82 & -157.82 \\
\hline 11 & $12 \mathrm{M} \mathrm{TN}$ & 17.9 & $\mathrm{ng} / \mu \mathrm{l}$ & 1.8 & 3.4 & 11.17 & 12.83 \\
\hline 12 & $15 \mathrm{M} \mathrm{TN}$ & 5.9 & $\mathrm{ng} / \mu \mathrm{l}$ & 1.91 & -16.54 & 33.90 & -9.90 \\
\hline 13 & $16 \mathrm{M} \mathrm{TN}$ & 17 & $\mathrm{ng} / \mu \mathrm{l}$ & 1.75 & 1.05 & 11.76 & 12.24 \\
\hline 14 & $17 \mathrm{M} \mathrm{TN}$ & 33.1 & $\mathrm{ng} / \mu \mathrm{l}$ & 1.81 & 2.68 & 6.04 & 17.96 \\
\hline 15 & $18 \mathrm{M} \mathrm{TN}$ & 54.5 & $\mathrm{ng} / \mu \mathrm{l}$ & 1.75 & 2.28 & 3.67 & 20.33 \\
\hline 16 & $19 \mathrm{M} \mathrm{TN}$ & 11.6 & $\mathrm{ng} / \mu \mathrm{l}$ & 1.72 & 2.34 & 17.24 & 6.76 \\
\hline 17 & $21 \mathrm{M} \mathrm{TN}$ & 46.7 & $\mathrm{ng} / \mu \mathrm{l}$ & 1.76 & 2.5 & 4.28 & 19.72 \\
\hline 18 & $23 \mathrm{M} \mathrm{TN}$ & 9.2 & $\mathrm{ng} / \mu \mathrm{l}$ & 1.56 & 0.75 & 21.74 & 2.26 \\
\hline 19 & $24 \mathrm{M} \mathrm{TN}$ & 8.7 & $\mathrm{ng} / \mu \mathrm{l}$ & 1.55 & 1.76 & 22.99 & 1.01 \\
\hline 20 & $25 \mathrm{M} \mathrm{TN}$ & 20.6 & $\mathrm{ng} / \mu \mathrm{l}$ & 1.71 & 2.73 & 9.71 & 14.29 \\
\hline 1 & 1M TT & 25.2 & $\mathrm{ng} / \mu \mathrm{l}$ & 1.48 & 0.59 & 7.94 & 16.06 \\
\hline 2 & 2M TT & 3.9 & $\mathrm{ng} / \mu \mathrm{l}$ & 1.63 & 22.87 & 51.28 & -27.28 \\
\hline 3 & 3M TT & 390.5 & $\mathrm{ng} / \mu \mathrm{l}$ & 1.81 & 2.14 & 0.51 & 23.49 \\
\hline 4 & 4M TT & 2.9 & $\mathrm{ng} / \mu \mathrm{l}$ & 1.23 & -1.35 & 68.97 & -44.97 \\
\hline 5 & 5M TT & 11.1 & $\mathrm{ng} / \mu \mathrm{l}$ & 1.79 & 2.78 & 18.02 & 5.98 \\
\hline 6 & $6 \mathrm{M} \mathrm{TT}$ & 6.9 & $\mathrm{ng} / \mu \mathrm{l}$ & 1.48 & 0.81 & 28.99 & -4.99 \\
\hline 7 & 7M TT & 94.1 & $\mathrm{ng} / \mu \mathrm{l}$ & 1.76 & 1.62 & 2.13 & 21.87 \\
\hline 8 & $8 \mathrm{M} \mathrm{TT}$ & 25.9 & $\mathrm{ng} / \mu \mathrm{l}$ & 1.73 & 3 & 7.72 & 16.28 \\
\hline 9 & 9M TT & 90.2 & $\mathrm{ng} / \mu \mathrm{l}$ & 1.72 & 2 & 2.22 & 21.78 \\
\hline 10 & 10M TT & 39.6 & $\mathrm{ng} / \mu \mathrm{l}$ & 1.63 & 1.64 & 5.05 & 18.95 \\
\hline 11 & 11M TT & 234.1 & $\mathrm{ng} / \mu \mathrm{l}$ & 1.67 & 2.15 & 0.85 & 23.15 \\
\hline 12 & 12M TT & 566.6 & $\mathrm{ng} / \mu \mathrm{l}$ & 1.81 & 2.15 & 0.35 & 23.65 \\
\hline 13 & 13M TT & 158.4 & $\mathrm{ng} / \mu \mathrm{l}$ & 1.77 & 1.66 & 1.26 & 22.74 \\
\hline 14 & 14M TT & 698 & $\mathrm{ng} / \mu \mathrm{l}$ & 1.79 & 1.92 & 0.29 & 23.71 \\
\hline 15 & 15M TT & 79 & $\mathrm{ng} / \mu \mathrm{l}$ & 1.77 & 2.13 & 2.53 & 21.47 \\
\hline 16 & 16M TT & 32.5 & $\mathrm{ng} / \mu \mathrm{l}$ & 1.7 & 1.84 & 6.15 & 17.85 \\
\hline 17 & 17M TT & 10.1 & $\mathrm{ng} / \mu \mathrm{l}$ & 1.81 & 6.42 & 19.80 & 4.20 \\
\hline 18 & $18 \mathrm{M}$ TT & 190.7 & $\mathrm{ng} / \mu \mathrm{l}$ & 1.76 & 1.98 & 1.05 & 22.95 \\
\hline 19 & 19M TT & 102.6 & $\mathrm{ng} / \mu \mathrm{l}$ & 1.72 & 2.03 & 1.95 & 22.05 \\
\hline 20 & $20 \mathrm{M} \mathrm{TT}$ & 44.7 & $\mathrm{ng} / \mu \mathrm{l}$ & 1.75 & 2.54 & 4.47 & 19.53 \\
\hline 21 & 21M TT & 46 & $\mathrm{ng} / \mu \mathrm{l}$ & 1.73 & 2.21 & 4.35 & 19.65 \\
\hline 22 & 22M TT & 399.6 & $\mathrm{ng} / \mu \mathrm{l}$ & 1.77 & 2.05 & 0.50 & 23.50 \\
\hline 23 & $23 \mathrm{M}$ TT & 11.7 & $\mathrm{ng} / \mu \mathrm{l}$ & 1.64 & 1.2 & 17.09 & 6.91 \\
\hline 24 & $24 \mathrm{M}$ TT & 24.1 & $\mathrm{ng} / \mu \mathrm{l}$ & 1.76 & 2.09 & 8.30 & 15.70 \\
\hline 25 & 25M TT & 70.8 & $\mathrm{ng} / \mu \mathrm{l}$ & 1.69 & 1.74 & 2.82 & 21.18 \\
\hline
\end{tabular}

Table S1. Mastectomy samples, DNA extraction results. Abbreviations: TT=tumoral tissue, TN=normal tissue 


\begin{tabular}{|c|c|c|c|c|c|c|c|}
\hline$\#$ & $\begin{array}{l}\text { Sample } \\
\text { ID }\end{array}$ & $\begin{array}{l}\text { ADN } \\
\text { Conc. }\end{array}$ & Unit & $260 / 280$ & $260 / 230$ & $\begin{array}{l}\text { DNA } \\
\text { (200 ng) }\end{array}$ & $\mathrm{H} 2 \mathrm{O}$ \\
\hline 1 & $1 \mathrm{~S} \mathrm{TN}$ & 49.4 & $\mathrm{ng} / \mu \mathrm{l}$ & 1.71 & 2.07 & 4.05 & 19.95 \\
\hline 2 & $2 \mathrm{~S} \mathrm{TN}$ & 100.2 & $\mathrm{ng} / \mu \mathrm{l}$ & 1.76 & 2.42 & 2.00 & 22.00 \\
\hline 3 & $3 \mathrm{~S} T \mathrm{TN}$ & -0.9 & $\mathrm{ng} / \mathrm{\mu l}$ & -0.63 & 0.3 & -222.22 & 246.22 \\
\hline 4 & $4 \mathrm{~S} \mathrm{TN}$ & 16 & $\mathrm{ng} / \mu \mathrm{l}$ & 1.53 & 3.88 & 12.50 & 11.50 \\
\hline 5 & $6 \mathrm{~S} \mathrm{TN}$ & 3.2 & $\mathrm{ng} / \mu \mathrm{l}$ & 0.89 & 19.84 & 62.50 & -38.50 \\
\hline 6 & $7 \mathrm{~S} \mathrm{TN}$ & 3.5 & $\mathrm{ng} / \mu \mathrm{l}$ & 0.84 & -2.58 & 57.14 & -33.14 \\
\hline 7 & $8 \mathrm{~S} \mathrm{TN}$ & 7 & $\mathrm{ng} / \mu \mathrm{l}$ & 1.16 & -1804.79 & 28.57 & -4.57 \\
\hline 8 & $12 \mathrm{~S} T \mathrm{~T}$ & 1.2 & $\mathrm{ng} / \mu \mathrm{l}$ & 0.47 & -0.61 & 166.67 & -142.67 \\
\hline 9 & $13 \mathrm{~S} \mathrm{TN}$ & 12.6 & $\mathrm{ng} / \mu \mathrm{l}$ & 1.44 & 3.05 & 15.87 & 8.13 \\
\hline 10 & $14 \mathrm{~S} \mathrm{TN}$ & 0.1 & $\mathrm{ng} / \mu \mathrm{l}$ & 0.06 & -0.05 & 2000.00 & $\begin{array}{l}- \\
1976.00 \\
\end{array}$ \\
\hline 11 & $16 \mathrm{STN}$ & 28.2 & $\mathrm{ng} / \mu \mathrm{l}$ & 1.69 & 2.96 & 7.09 & 16.91 \\
\hline 12 & $19 \mathrm{~S} \mathrm{TN}$ & 152 & $\mathrm{ng} / \mu \mathrm{l}$ & 1.78 & 2.24 & 1.32 & 22.68 \\
\hline 13 & $20 S \mathrm{TN}$ & 22.4 & $\mathrm{ng} / \mu \mathrm{l}$ & 1.55 & 2.02 & 8.93 & 15.07 \\
\hline 14 & $22 \mathrm{~S} T \mathrm{TN}$ & -0.6 & $\mathrm{ng} / \mu \mathrm{l}$ & -0.31 & -0.07 & -333.33 & 357.33 \\
\hline 15 & $25 \mathrm{~S} \mathrm{TN}$ & -2.2 & $\mathrm{ng} / \mu \mathrm{l}$ & -4.05 & 0.78 & -90.91 & 114.91 \\
\hline 16 & $26 \mathrm{~S} \mathrm{TN}$ & 2.7 & $\mathrm{ng} / \mu \mathrm{l}$ & 0.77 & -1.51 & 74.07 & -50.07 \\
\hline 17 & $29 \mathrm{~S} T \mathrm{~N}$ & 128.2 & $\mathrm{ng} / \mu \mathrm{l}$ & 1.77 & 2.64 & 1.56 & 22.44 \\
\hline 18 & $30 \mathrm{STN}$ & 2.8 & $\mathrm{ng} / \mu \mathrm{l}$ & 1.49 & -0.64 & 71.43 & -47.43 \\
\hline 19 & $31 \mathrm{~S} \mathrm{TN}$ & 1.4 & $\mathrm{ng} / \mu \mathrm{l}$ & 2.05 & -0.2 & 142.86 & -118.86 \\
\hline 20 & $32 \mathrm{STN}$ & 5.2 & $\mathrm{ng} / \mu \mathrm{l}$ & 1.82 & -1.07 & 38.46 & -14.46 \\
\hline 21 & $34 \mathrm{~S} \mathrm{TN}$ & 6.9 & $\mathrm{ng} / \mu \mathrm{l}$ & 1.63 & 19.18 & 28.99 & -4.99 \\
\hline 22 & $35 \mathrm{~S} \mathrm{TN}$ & 34.1 & $\mathrm{ng} / \mu \mathrm{l}$ & 1.68 & 3.35 & 5.87 & 18.13 \\
\hline 23 & $38 \mathrm{~S} \mathrm{TN}$ & 4.7 & $\mathrm{ng} / \mu \mathrm{l}$ & 1.83 & -0.81 & 42.55 & -18.55 \\
\hline 24 & $39 \mathrm{~S}$ TN & 6.8 & $\mathrm{ng} / \mu \mathrm{l}$ & 1.74 & -2.63 & 29.41 & -5.41 \\
\hline 25 & $40 \mathrm{STN}$ & 15.6 & $\mathrm{ng} / \mu \mathrm{l}$ & 1.71 & -17.58 & 12.82 & 11.18 \\
\hline 26 & 41S TN & 1.5 & $\mathrm{ng} / \mu \mathrm{l}$ & 1.74 & -0.21 & 133.33 & -109.33 \\
\hline 27 & $42 \mathrm{STN}$ & 136.2 & $\mathrm{ng} / \mu \mathrm{l}$ & 1.56 & 2.33 & 1.47 & 22.53 \\
\hline 28 & $43 \mathrm{~S} \mathrm{TN}$ & 15.1 & $\mathrm{ng} / \mu \mathrm{l}$ & 1.56 & 11.59 & 13.25 & 10.75 \\
\hline 29 & $46 \mathrm{~S} \mathrm{TN}$ & 5.7 & $\mathrm{ng} / \mu \mathrm{l}$ & 1.87 & -1.22 & 35.09 & -11.09 \\
\hline 30 & $47 \mathrm{~S} \mathrm{TN}$ & 8.6 & $\mathrm{ng} / \mu \mathrm{l}$ & 1.69 & -2.2 & 23.26 & 0.74 \\
\hline 31 & $48 \mathrm{~S} \mathrm{TN}$ & 169.5 & $\mathrm{ng} / \mu \mathrm{l}$ & 1.65 & 2.31 & 1.18 & 22.82 \\
\hline 32 & $50 \mathrm{STN}$ & 12.6 & $\mathrm{ng} / \mu \mathrm{l}$ & 1.82 & -7.08 & 15.87 & 8.13 \\
\hline 1 & $1 \mathrm{~S} \mathrm{TT}$ & 120.7 & $\mathrm{ng} / \mu \mathrm{l}$ & 1.69 & 2.28 & 1.66 & 22.34 \\
\hline 2 & 2S TT & 107.2 & $\mathrm{ng} / \mu \mathrm{l}$ & 1.72 & 2.21 & 1.87 & 22.13 \\
\hline 3 & 3S TT & 5.9 & $\mathrm{ng} / \mu \mathrm{l}$ & 1.75 & -19.58 & 33.90 & -9.90 \\
\hline 4 & 4S TT & 91.9 & $\mathrm{ng} / \mu \mathrm{l}$ & 1.69 & 2.4 & 2.18 & 21.82 \\
\hline 5 & $5 \mathrm{~S} \mathrm{TT}$ & 23.2 & $\mathrm{ng} / \mu \mathrm{l}$ & 1.89 & 2.78 & 8.62 & 15.38 \\
\hline 6 & 6S TT & 43.7 & $\mathrm{ng} / \mu \mathrm{l}$ & 1.76 & 1.87 & 4.58 & 19.42 \\
\hline
\end{tabular}




\begin{tabular}{|c|c|c|c|c|c|c|c|}
\hline 7 & 7S TT & 7.3 & $\mathrm{ng} / \mu \mathrm{l}$ & 1.81 & 2.89 & 27.40 & -3.40 \\
\hline 8 & 8S TT & 24.8 & $\mathrm{ng} / \mu \mathrm{l}$ & 1.57 & 1.33 & 8.06 & 15.94 \\
\hline 9 & 9S TT & 9.5 & $\mathrm{ng} / \mu \mathrm{l}$ & 1.61 & 1.41 & 21.05 & 2.95 \\
\hline 10 & 10S TT & 6.1 & $\mathrm{ng} / \mu \mathrm{l}$ & 1.74 & 0.87 & 32.79 & -8.79 \\
\hline 11 & 11S TT & 131.3 & $\mathrm{ng} / \mu \mathrm{l}$ & 1.76 & 2.03 & 1.52 & 22.48 \\
\hline 12 & 13S TT & 25.7 & $\mathrm{ng} / \mu \mathrm{l}$ & 1.8 & 2.38 & 7.78 & 16.22 \\
\hline 13 & 14S TT & 10.3 & $\mathrm{ng} / \mu \mathrm{l}$ & 1.81 & 1.33 & 19.42 & 4.58 \\
\hline 14 & 15S TT & 13 & $\mathrm{ng} / \mu \mathrm{l}$ & 1.82 & 2.66 & 15.38 & 8.62 \\
\hline 15 & 16S TT & 71.5 & $\mathrm{ng} / \mu \mathrm{l}$ & 1.8 & 2.41 & 2.80 & 21.20 \\
\hline 16 & 17S TT & 38.6 & $\mathrm{ng} / \mu \mathrm{l}$ & 1.77 & 2.62 & 5.18 & 18.82 \\
\hline 17 & 18S TT & 12.4 & $\mathrm{ng} / \mu \mathrm{l}$ & 1.84 & 2.42 & 16.13 & 7.87 \\
\hline 18 & 19S TT & 10.7 & $\mathrm{ng} / \mu \mathrm{l}$ & 1.89 & 2.22 & 18.69 & 5.31 \\
\hline 19 & 20S TT & 24.6 & $\mathrm{ng} / \mu \mathrm{l}$ & 1.84 & 2.79 & 8.13 & 15.87 \\
\hline 20 & $21 \mathrm{~S} T \mathrm{~T}$ & 6.1 & $\mathrm{ng} / \mu \mathrm{l}$ & 1.68 & 1.15 & 32.79 & -8.79 \\
\hline 21 & $22 \mathrm{~S} \mathrm{TT}$ & 25.9 & $\mathrm{ng} / \mu \mathrm{l}$ & 1.73 & 2.02 & 7.72 & 16.28 \\
\hline 22 & 23S TT & 17.5 & $\mathrm{ng} / \mu \mathrm{l}$ & 1.96 & 2.9 & 11.43 & 12.57 \\
\hline 23 & $24 \mathrm{~S}$ TT & 31.3 & $\mathrm{ng} / \mu \mathrm{l}$ & 1.76 & 2.41 & 6.39 & 17.61 \\
\hline 24 & 25S TT & 28.1 & $\mathrm{ng} / \mu \mathrm{l}$ & 1.63 & 1.04 & 7.12 & 16.88 \\
\hline 25 & 26S TT & 23.4 & $\mathrm{ng} / \mu \mathrm{l}$ & 1.7 & 2.52 & 8.55 & 15.45 \\
\hline 26 & 27S TT & 12.3 & $\mathrm{ng} / \mu \mathrm{l}$ & 1.78 & 2.16 & 16.26 & 7.74 \\
\hline 27 & 28S TT & 5.1 & $\mathrm{ng} / \mu \mathrm{l}$ & 1.6 & 2.6 & 39.22 & -15.22 \\
\hline 28 & 29S TT & 11.1 & $\mathrm{ng} / \mu \mathrm{l}$ & 1.91 & 3.5 & 18.02 & 5.98 \\
\hline 29 & $30 \mathrm{STT}$ & 4.2 & $\mathrm{ng} / \mu \mathrm{l}$ & 1.94 & 3.28 & 47.62 & -23.62 \\
\hline 30 & $31 \mathrm{STT}$ & 13.1 & $\mathrm{ng} / \mu \mathrm{l}$ & 1.71 & 2.1 & 15.27 & 8.73 \\
\hline 31 & $32 \mathrm{STT}$ & 15.2 & $\mathrm{ng} / \mu \mathrm{l}$ & 1.79 & 2.25 & 13.16 & 10.84 \\
\hline 32 & 33S TT & 68.4 & $\mathrm{ng} / \mu \mathrm{l}$ & 1.65 & 0.9 & 2.92 & 21.08 \\
\hline 33 & $34 \mathrm{~S}$ TT & 5 & $\mathrm{ng} / \mu \mathrm{l}$ & 1.49 & 1.75 & 40.00 & -16.00 \\
\hline 34 & 35S TT & 7.3 & $\mathrm{ng} / \mu \mathrm{l}$ & 1.45 & 0.67 & 27.40 & -3.40 \\
\hline 35 & $36 \mathrm{~S} \mathrm{TT}$ & 10.6 & $\mathrm{ng} / \mu \mathrm{l}$ & 1.79 & 3.5 & 18.87 & 5.13 \\
\hline 36 & $37 \mathrm{~S}$ TT & 4.1 & $\mathrm{ng} / \mu \mathrm{l}$ & 1.69 & 84.43 & 48.78 & -24.78 \\
\hline 37 & $38 \mathrm{~S}$ TT & 27.4 & $\mathrm{ng} / \mu \mathrm{l}$ & 1.74 & 2.73 & 7.30 & 16.70 \\
\hline 38 & 40S TT & 13.6 & $\mathrm{ng} / \mu \mathrm{l}$ & 1.64 & 2.33 & 14.71 & 9.29 \\
\hline 39 & $41 \mathrm{~S} T \mathrm{~T}$ & 92.4 & $\mathrm{ng} / \mu \mathrm{l}$ & 1.63 & 2.36 & 2.16 & 21.84 \\
\hline 40 & $42 \mathrm{~S} T \mathrm{~T}$ & 60.2 & $\mathrm{ng} / \mu \mathrm{l}$ & 1.55 & 2.3 & 3.32 & 20.68 \\
\hline 41 & 43S TT & 45.6 & $\mathrm{ng} / \mu \mathrm{l}$ & 1.57 & 2.32 & 4.39 & 19.61 \\
\hline 42 & 44S TT & 0.6 & $\mathrm{ng} / \mu \mathrm{l}$ & 0.94 & -0.2 & 333.33 & -309.33 \\
\hline 43 & 45S TT & 9.7 & $\mathrm{ng} / \mu \mathrm{l}$ & 1.62 & 6.66 & 20.62 & 3.38 \\
\hline 44 & $46 \mathrm{~S}$ TT & 18 & $\mathrm{ng} / \mu \mathrm{l}$ & 1.65 & 3.66 & 11.11 & 12.89 \\
\hline 45 & 47S TT & 223.4 & $\mathrm{ng} / \mu \mathrm{l}$ & 1.58 & 1.64 & 0.90 & 23.10 \\
\hline 46 & $48 \mathrm{~S}$ TT & 58.8 & $\mathrm{ng} / \mu \mathrm{l}$ & 1.58 & 2.11 & 3.40 & 20.60 \\
\hline 47 & 49S TT & 29.4 & $\mathrm{ng} / \mu \mathrm{l}$ & 1.64 & 1.89 & 6.80 & 17.20 \\
\hline 48 & 50S TT & 31.4 & $\mathrm{ng} / \mu \mathrm{l}$ & 1.67 & 2.33 & 6.37 & 17.63 \\
\hline
\end{tabular}


Table S2. Lumpectomy samples, DNA extraction results. Abbreviations: TT=tumoral tissue, $\mathrm{TN}=$ normal tissue

Author Contributions: Conceptualization, Z.F., B.O.T..; methodology, Z.F., B.O.T., L.R.; formal analysis, L.R.; resources, Z.F., D.T.E, R.B., M.G.; data curation, Z.F., B.O.T., R.B., L.R.; writing-original draft preparation, Z.F., B.O.T., L.R.; writing-review and editing, Z.F.; visualization, Z.F., B.O.T., L.R.; supervision, I. B-N.; project administration, I. B-N.; funding acquisition, Z.F., B.O.T., L.R. All authors have read and agreed to the published version of the manuscript.

Funding: This research was funded by an internal grant of the Iuliu Hațieganu University of Medicine and Pharmacy.

Institutional Review Board Statement: The study was conducted according to the guidelines of the Declaration of Helsinki, and approved by the Ethics Committee of Iuliu Hațieganu University of Medicine and Pharmacy (Apr 2016). The number of ethics approval is 199/10 May 2016.

Informed Consent Statement: Informed consent was obtained from all subjects involved in the study.

Conflicts of Interest: The authors declare no conflict of interest.

\section{References}

1. Sung H, Ferlay J, Siegel RL, Laversanne M, Soerjomataram I, Jemal A, et al. Global cancer statistics 2020: GLOBOCAN estimates of incidence and mortality worldwide for 36 cancers in 185 countries. CA Cancer J Clin. 2021, 71, 209-249. https://doi.org/10.3322/caac. 21660

2. Momenimovahed Z, Salehiniya H. Epidemiological characteristics of and risk factors for breast cancer in the world. Breast Cancer: Targets and Therapy. 2019, 11, 151-164. https://doi.org/10.2147/BCTT.S176070

3. Thakur P, Seam RK, Gupta MK, Gupta M, Sharma M, Fotedar V. Breast cancer risk factor evaluation in a Western Himalayan state: A case-control study and comparison with the Western World. South Asian J Cancer. 2017, 06, 106-109. https://doi.org/10.4103/sajc.sajc_157_16

4. Metcalfe KA, Finch A, Poll A, Horsman D, Kim-Sing C, Scott J, et al. Breast cancer risks in women with a family history of breast or ovarian cancer who have tested negative for a BRCA1 or BRCA2 mutation. Br J Cancer. 2009, 100, $421-425$. https://doi.org/10.4103/sajc.sajc_157_16

5. Marchbanks PA, McDonald JA, Wilson HG, Folger SG, Mandel MG, Daling JR, et al. Oral Contraceptives and the Risk of Breast Cancer. N Engl J Med. 2002, 346, 2025-2032. https://doi.org/10.1056/NEJMoa013202

6. Brinton LA, Scoccia B, Moghissi KS, Westhoff CL, Althuis MD, Mabie JE, et al. Breast cancer risk associated with ovulationstimulating drugs. Hum Reprod. 2004, 19, 2005-2013. https://doi.org/10.1158/1055-9965.

7. Collaborative Group on Hormonal Factors in Breast Cancer. Type and timing of menopausal hormone therapy and breast cancer risk: individual participant meta-analysis of the worldwide epidemiological evidence. Lancet, 2019, 394, $1159-1168$. https://doi.org/10.1016/S0140-6736(19)31709-X

8. Miller ER, Wilson C, Chapman J, Flight I, Nguyen AM, Fletcher C, et al. Connecting the dots between breast cancer, obesity and alcohol consumption in middle-aged women: Ecological and case control studies. BMC Public Health. 2018, 18, 460. https://doi.org/10.1186/s12889-018-5357-1

9. Schiller JT, Lowy DR. Virus infection and human cancer: An overview. Vol. 193, Recent Results in Cancer Research. 2014, 193, 110. https://doi.org/10.1007/978-3-642-38965-8_1

10. Hennighausen L. Mouse models for breast cancer. Oncogene. 2000, 19, 966-967. https://doi.org/10.1038/sj.onc.1203346

11. Axel R, Schlom J, Spiegelman S. Presence in human breast cancer of RNA homologous to mouse mammary tumour virus RNA. Nature. 1972, 235, 32-36. https://doi.org/10.1038/235032a0

12. Szakacs JG, Moscinski LC. Sequence homology of deoxyribonucleic acid to mouse mammary tumor virus genome in human breast tumors. Ann Clin Lab Sci. 1991, 21, 402-412. PMID: 1664195.

13. Salmons B, Lawson JS, Günzburg WH. Recent developments linking retroviruses to human breast cancer: Infectious agent, Enemy within or both? J Gen Virol, 2014, 95, 2589-2593. https://doi.org/10.1099/vir.0.070631-0.

14. Melana SM, Picconi MA, Rossi C, Mural J, Alonio LV, Teyssié A, Holland JF, Pogo BGT [Detection of murine mammary tumor virus (MMTV) env gene-like sequences in breast cancer from Argentine patients]. Medicina (B Aires). 2002, 62, 323-327. PMID: 12325488

15. Wang Y, Holland JF, Bleiweiss IJ, Melana S, Liu X, Pelisson I, et al. Detection of Mammary Tumor Virus ENV Gene-like Sequences in Human Breast Cancer. Cancer Res. 1995, 55, 5173-5179. PMID: 7585568

16. Mazzanti CM, Al Hamad M, Fanelli G, Scatena C, Zammarchi F, Zavaglia K, et al. A mouse mammary tumor virus env-like exogenous sequence is strictly related to progression of human sporadic breast carcinoma. Am J Pathol. 2011, 179, $2083-2090$. https://doi.org/10.1016/j.ajpath.2011.06.046

17. Freeman MD, Gopman JM, Salzberg CA. The evolution of mastectomy surgical technique: from mutilation to medicine. Gland Surgery, 2017, 7, 308-315. https://doi.org/10.21037/gs.2017.09.07.

18. Mason A. Is there a breast cancer virus? Ochsner J. 2000, 2, 36-39. PMID: 21765660 
19. Morris DW, Dutra JC. Identification of a MMTV insertion mutation with the coding region of the Fgf-3 protooncogene. Virology. 1997, 238, 161-165.

20. Tabriz HM, Zendehdel K, Shahsiah R, Fereidooni F, Mehdipour B, Hosseini ZM. Lack of detection of the mouse mammary tumor-like virus (MMTV) env gene in iranian women breast cancer using real time PCR. Asian Pacific J Cancer Prev. 2013, 14, 2945-2948. https://doi.org/10.7314/apjcp.2013.14.5.2945

21. Perzova R, Abbott L, Benz P, Landas S, Khan S, Glaser J, et al. Is MMTV associated with human breast cancer? Maybe, but probably not. Virol J. 2017, 14. https://doi.org/10.1186/s12985-017-0862-x

22. Fukuoka H, Moriuchi M, Yano H, Nagayasu T, Moriuchi H. No association of mouse mammary tumor virus-related retrovirus with Japanese cases of breast cancer. J Med Virol. 2008, 80, 1447-1451. https://doi.org/10.1002/jmv.21247.

23. Etkind P, Du J, Khan A, Pillitteri J, Wiernik PH. Mouse Mammary Tumor Virus-like ENV Gene Sequences in Human Breast Tumors and in a Lymphoma of a Breast Cancer Patient. Clin Cancer Res., 2000, 4, 1273-1278.

24. Ford CE, Tran D, Deng Y, Ta VT, Rawlinson WD, Lawson JS. Mouse Mammary Tumor Virus-like Gene Sequences in Breast Tumors of Australian and Vietnamese Women, Clin Cancer Res, 2003, 9, 1118-1120.

25. Al Dossary R, Alkharsah KR, Kussaibi H. Prevalence of Mouse Mammary Tumor Virus (MMTV)-like sequences in human breast cancer tissues and adjacent normal breast tissues in Saudi Arabia. BMC Cancer. 2018, 18, 1-10. https://doi.org/10.1186/s12885-018-4074-6

26. Johal H, Ford C, Glenn W, Heads J, Lawson J, Rawlinson W. Mouse mammary tumor like virus sequences in breast milk from healthy lactating women. Breast Cancer Res Treat, 2011, 129, 149-155. https://doi.org/10.1007/s10549-011-1421-6

27. Mazzanti CM, Lessi F, Armogida I, Zavaglia K, Franceschi S, Al Hamad M, et al. Human saliva as route of inter-human infection for mouse mammary tumor virus. Oncotarget. 2015, 6, 18355-18363.

28. Naushad W, Ayub S, Sadia H, Ahmad Joyia F. Significant correlation of MMTV (Mouse mammary tumor virus) LTR gene with hormone receptor status in peripheral blood samples of breast cancer patients from North Pakistan. Int J Biosci, 2017, 10, 399405. http://dx.doi.org/10.12692/ijb/10.3.399-405

29. Stewart THM, Sage RD, Stewart AFR, Cameron DW. Breast cancer incidence highest in the range of one species of house mouse, Mus domesticus. Br J Cancer. 2000, 82, 446-451. http://dx.doi.org/10.1054/bjoc.1999.0941

30. Forejt J, Hybrid Sterility, Mouse. In Brenner's Encyclopedia of Genetics; 2nd ed. Maloy S., Hughes K., Eds.; Elsevier: Publisher Amsterdam, Netherlands, 2013; pp. 582-585. DOI: 10.1016/B978-0-12-809633-8.06558-4.

31. R Callahan, W Drohan, D Gallahan, L D'Hoostelaere, M Potter. Novel class of mouse mammary tumor virus-related DNA sequences found in all species of Mus, including mice lacking the virus proviral genome. Proceedings of the National Academy of Sciences, 1982, 79, 4113-4117; DOI: 10.1073/pnas.79.13.4113.

32. Rajabi-Maham H, Orth A, Bonhomme F. Phylogeography and postglacial expansion of Mus musculus domesticus inferred from mitochondrial DNA coalescent, from Iran to Europe. Mol Ecol. 2008, 17, 627-641. DOI: 10.1111/j.1365-294X.2007.03601.x.

33. García-Rodríguez O, Hardouin EA, Hambleton E, Monteith J, Randall C, Richards MB, Edwards CJ, Stewart JR. Ancient mitochondrial DNA connects house mice in the British Isles to trade across Europe over three millennia. BMC Ecol Evol. $2021,21,9$. DOI: $10.1186 / \mathrm{s} 12862-021-01746-4$.

34. Laumbacher B, Fellerhoff B, Herzberger B, Wank R. Do dogs harbour risk factors for human breast cancer? Med Hypotheses. 2006, 67, 21-26. DOI: 10.1016/j.mehy.2006.01.016.

35. Lehrer S, Rheinstein PH. The virology of breast cancer: viruses as the potential causative agents of breast tumorigenesis. Discov Med. 2019, 27, 163-166.

36. de Sousa Pereira N, Akelinghton Freire Vitiello G, Karina Banin-Hirata B, et al. Mouse Mammary Tumor Virus (MMTV)-Like Sequence in Brazilian Breast Cancer Samples: Implications in Clinicopathological Parameters in Molecular Subtypes. International Journal of Environmental Research and Public Health. 2020, 24. DOI: 10.3390/ijerph17249496..

37. Buehring GC, Shen HM, Jensen HM, Jin DL, Hudes M, et al. (2015) Exposure to Bovine Leukemia Virus Is Associated with Breast Cancer: A Case-Control Study. PLOS ONE, 2015, 10, e0134304. https://doi.org/10.1371/journal.pone.0134304 